
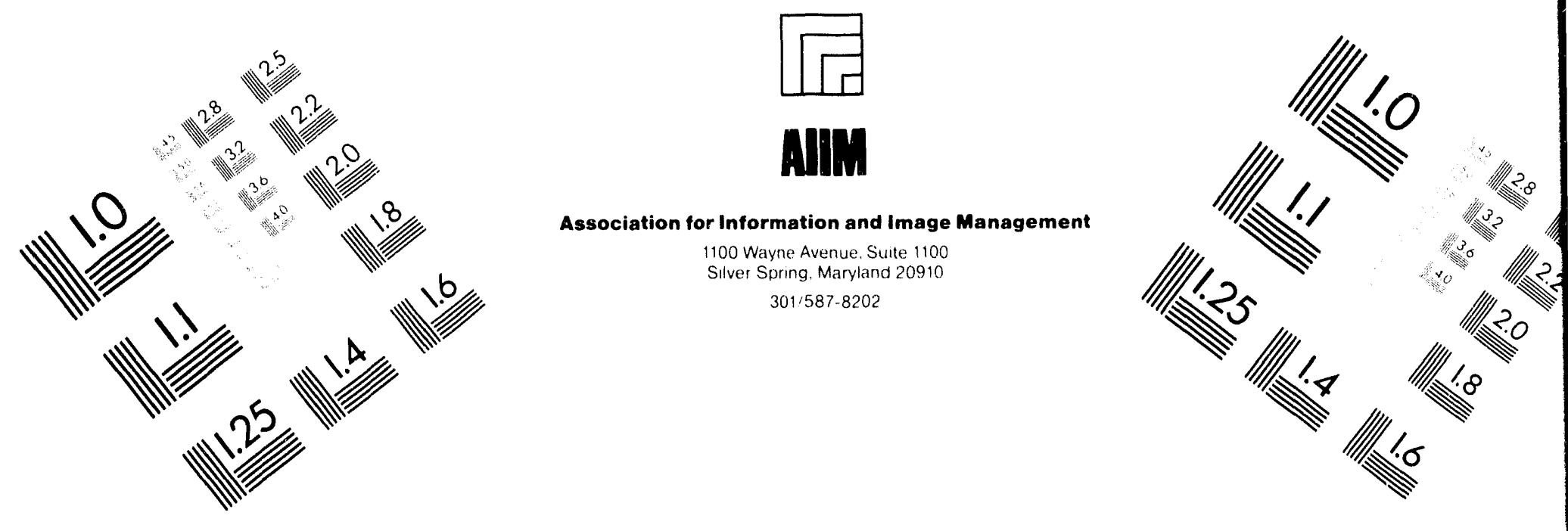

Centimeter

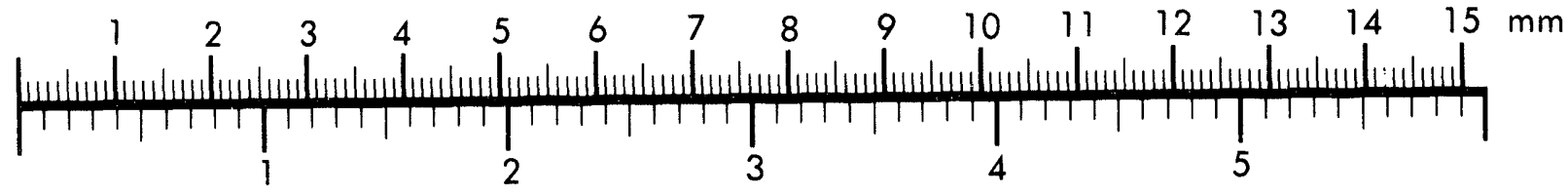

Inches
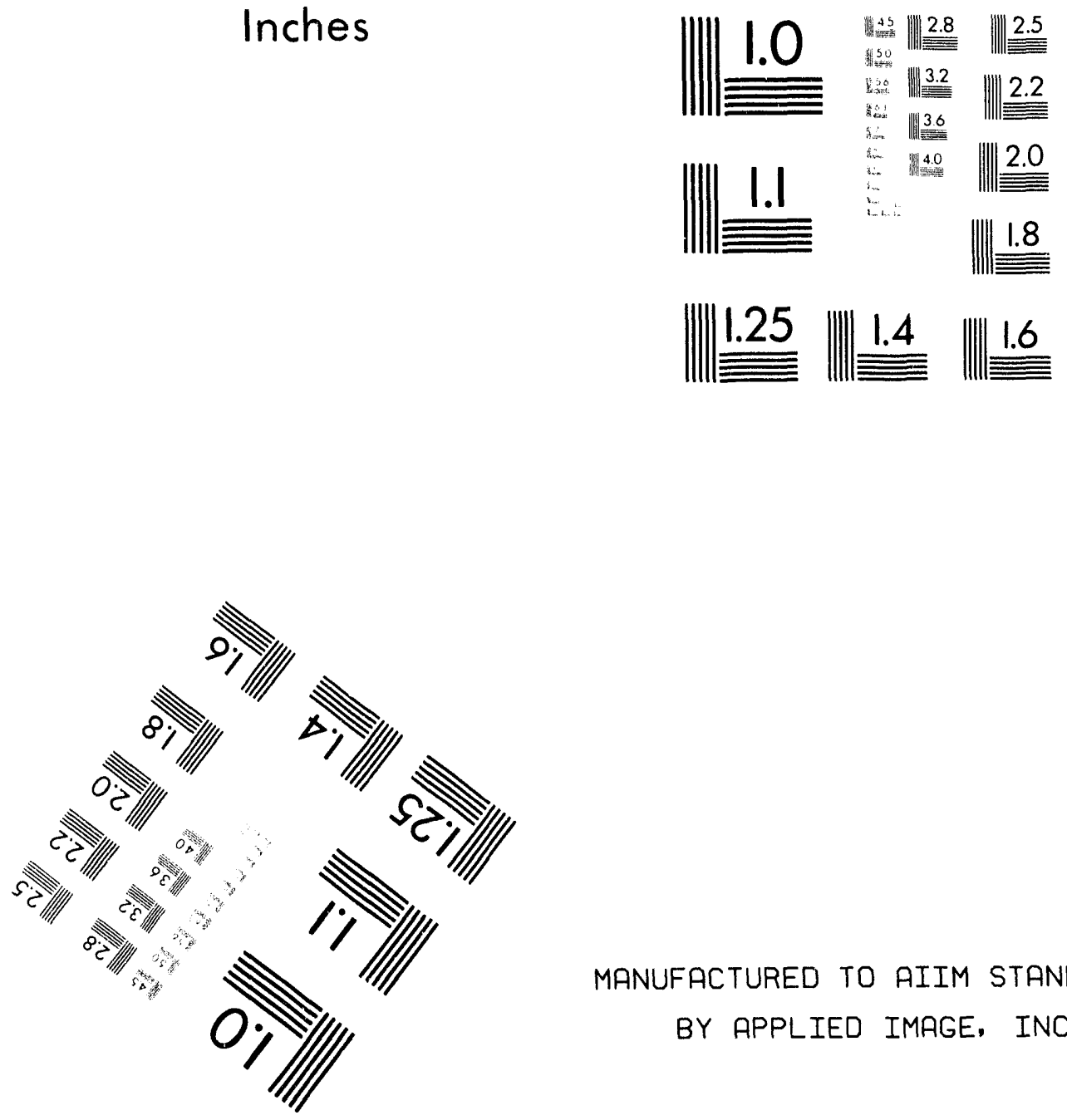

MANUFACTURED TO AIIM STANDARDS

BY APPLIED IMAGE, INC.

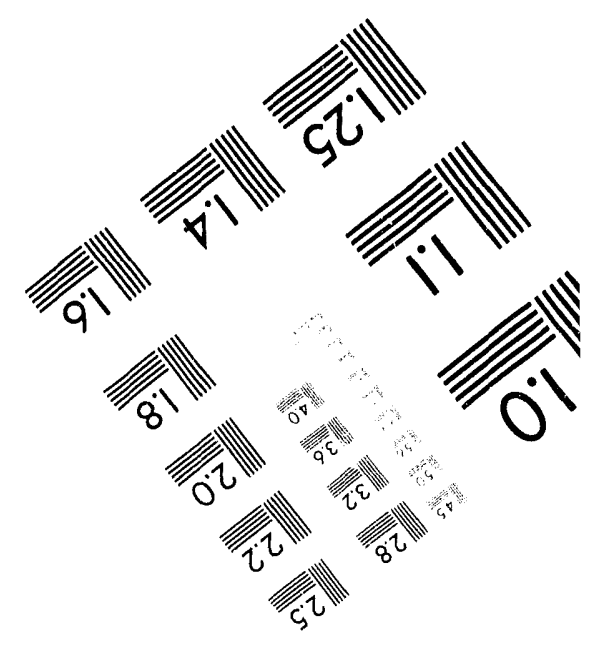





\section{Estimates of Durability \\ of TMI-2 Core Debris \\ Canisters and Cask Liners}
A. B. Johnson, Jr.
A. L. Lund
S. P. Pednekar

April 1994

Prepared for EG\&G, Idaho

Idaho National Engineering Laboratory

under a Related Services Agreement

with the U.S. Department of Energy

Contract DE-AC06-76RLO 1830

Pacific Northwest Laboratory

Operated for the U.S. Department of Energy

by Battelle Memorial Institute 


\title{
DISCLAIMER
}

This report was prepared as an account of work sponsored by an agency of the United States Government. Neither the United States Government nor any agency thereof, nor Battelle Memorial Institute, nor any of their employees, makes any warranty, expressed or implied, or assumes any legal liability or responsibility for the accuracy, completeness, or usefulness of any information, apparatus, product, or process disclosed, or represents that its use would not infringe privately owned rights. Reference herein to any specific commercial product, process, or service by trade name, trademark, manufacturer, or otherwise does not necessarily constitute or imply its endorsement, recommendation, or favoring by the United States Government or any agency thereof, or Battelle Memorial Institute. The views and opinions of authors expressed herein do not necessarily state or reflect those of the United States Government or any agency thereof.

\author{
PACIFIC NORTHWEST LABORATORY \\ operated by \\ BATTELLE MEMORIAL INSTITUTE \\ for the \\ UNITED STATES DEPARTMENT OF ENERGY \\ under Contract DE-AC06-76RLO 1830
}

Printed in the United States of America

Available to DOE and DOE contractors from the

Office of Scientific and Technical Information, P.O. Box 62, Oak Ridge, IN 37831; prices available from (615) 576-8401. FTS 626-8401.

Available to the public from the National Technical Information Service, U.S. Department of Commerce, 5285 Port Royal Rd., Springfield, VA 22161. 
PNL -9457

UC -804

ESTIMATES OF DURABILITY OF

TMI - 2 CORE DEBRIS CANISTERS

AND CASK LINERS

A. B. Johnson, Jr.

A. L. Lund

S. P. Pednekar

April 1994

Prepared for EG\&G, Idaho

Idaho National Engineering Laboratory

under a Related Services Agreement

with the U.S. Department of Energy

Contract DE-ACO6-76RLO 1830

Pacific Northwest Laboratory

Richland, Washington 99352 


\section{CONTENTS}

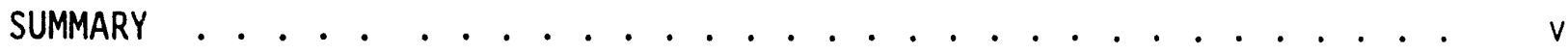

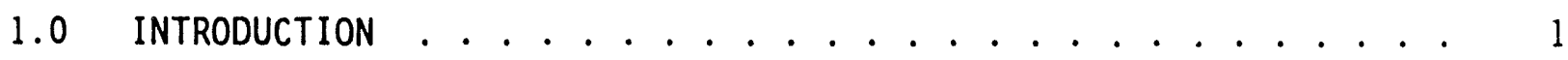

1.1 SCOPE OF THE ASSESSMENT . . . . . . . . . . . . . 1

1.2 APPROACH TO THE ASSESSMENT ................... 1

1.3 CHARACTERISTICS OF THE TMI-2 FUEL DEBRIS .......... 2

2.0 THERMODYNAMIC BASIS .................. . . . . 6

3.0 MATERIALS, DESIGNS, AND CONDITIONS ............. 9

3.1 MATERIALS ............................. 9

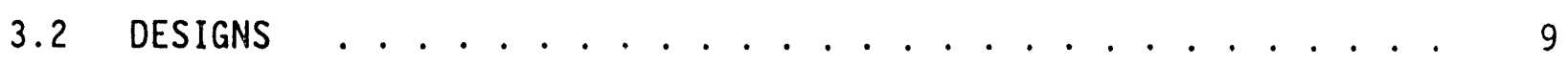

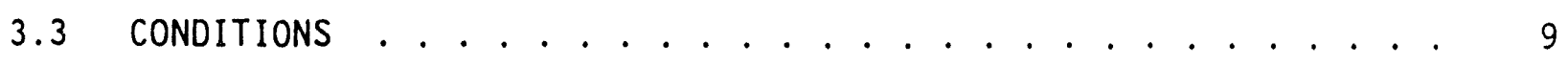

4.0 ESTIMATED TMI-2 CANISTER DURABILITY: $1986-2000 \ldots \ldots$

5.0 ESTIMATED TMI -2 CANISTER AND LINER DEGRADATION

6.0 DISCUSSION ............................ 32

7.0 REFERENCES ....................... 34 


\section{FIGURES}

FIGURE 1. Core Debris Canisters . . . . . . . . . . . . . . . 4

FIGURE 2. Potential pH Equilibrium Diagram for the System

Iron Water at $25^{\circ} \mathrm{C}$. . . . . . . . . . . . . . . . 8

\section{TABLES}

TABLE 1. Summary of TMI-2 Stainless Steel Canister

Environments . . . . . . . . . . . . . . . . . 5

TABLE 2. Canister and Cask Materials and Dimensions . . . . . . . 10

TABLE 3. Composition of Carbon Steel Cask Liner and

Stainless Steel Canister Materials . . . . . . . . . . . . 11

TABLE 4. Summary of Corrosion Estimates Beyond 2000 AD . . . . . . . 15 
SUMMARY

Core debris from the Three Mile Island-2 (TMI-2) reactor is currently stored in stainless steel canisters. The need to maintain the integrity of the TMI-2 core debris containers through the period of extended storage and possibly into disposal prompted this assessment. In the assessment, corrosion nduced degradation was estimated for two materials: type $304 \mathrm{~L}$ stainless steel (SS) canisters that contain the core debris, and type 1020 carbon steel (CS) liners in the concrete casks planned for containing the canisters from 2000 AD until the TMI-2 core debris is placed in a repository. Three environments were considered: air-saturated water (with $2 \mathrm{ppm} \mathrm{Cl}^{-}$) at $20^{\circ} \mathrm{C}$, and air at $20^{\circ} \mathrm{C}$ with two relative humidities (RHs), 10 and $40 \%$.

Corrosion mechanisms assessed included general corrosion (failure criterion: $50 \%$ loss of wall thickness) and localized attack (failure criterion: throughwall pinhole penetration). Estimation of carbon steel corrosion after $50 \mathrm{y}$ also was requested.

Durability of Stainless Steel Canisters

Estimates of stainless canister durability during handling, shipping, and wet storage at TMI-2 and the Idaho National Engineering Laboratory (INEL) over the period 1986 - 2000 AD suggest only $\sim 0.2 \mathrm{mil}{ }^{\text {(a) }}$ penetration by general corrosion and nil degradation by localized mechanisms.

The following long-term durability results were obtained for $304 \mathrm{~L}$ stainless steel in exposures beyond $2000 \mathrm{AD}$ in the environments indicated above:

- pinhole penetration:

- nil in water

- nil in air

- $\quad 50 \%$ wall thickness $10 s^{(b)}$ :

- $4600 y$ in water

- $11,500 y$ in air at $10 \%$ and $40 \% \mathrm{RH}$

The indicated durability of the stainless steel canisters reflects the high corrosion resistance of type $304 \mathrm{~L}$ stainless steel under the benign conditions expected to prevail in the concrete casks over the period of extended interim storage. Available data suggest that sensitization at welds will be sufficiently low to preclude intergranular penetrations. Corrosion data at $50^{\circ} \mathrm{C}$ indicate that pitting and crevice factors are close to 1.0 ,

(a) $1 \mathrm{mil}=0.001 \mathrm{in} .=25.4 \mu \mathrm{m}$

(b) The general canister wall thickness is $0.25 \mathrm{in} .=250 \mathrm{mils}$, but the bottom head thickness is $219 \mathrm{mils}$, which is used as the basis for calculations. 
suggesting that these mechanisms are not likely to proceed more rapidly than uniform corrosion, even if they initiate. Galvanic contacts with carbon steel are expected to cathodically polarize the stainless steel and, therefore, will not accelerate corrosion penetrations.

Data on uniform corrosion of type $304 \mathrm{~L}$ stainless steel were taken from studies in tuff groundwater at $100^{\circ} \mathrm{C}$ with $7.5 \mathrm{ppm} \mathrm{Cl}$ under a gamma flux. No attempt was made to extrapolate the corrosion data to the more benign conditions that apply to the TMI- 2 canisters because some data suggest that the corrosion may not be temperature dependent below $\sim 150^{\circ} \mathrm{C}$. Also, the higher gamma flux in the tuff groundwater tests had minimal influence on corrosion of the $304 \mathrm{~L}$ material. The estimated times for satisfactory durability of the TMI-2 canisters are conservative, but the degree depends on the currently unclear basis for extrapolation.

One of the requested criteria was $50 \%$ strength 10ss; this was interpreted to be represented by $50 \%$ penetration of the wall by uniform corrosion.

\section{Durability of Carbon Steel Cask Liners}

The following long-term durability results were obtained for type 1020 carbon steel:

$\begin{array}{lccc}\text { environment } & \frac{\text { penetration after }}{50 \mathrm{y}} & \frac{\text { time to through-wall }}{\text { pinhole penetration }} & \frac{\text { time to } 50 \% \text { wall }}{\text { thickness } 10 \mathrm{ss}} \\ \text { water } & 50 \mathrm{mils} & 750 \mathrm{y} & 375 \mathrm{y} \\ \text { air/10\% RH } & 5 \mathrm{mils} & 7500 \mathrm{y} & 3800 \mathrm{y} \\ \text { air } / 40 \% \mathrm{RH} & 10 \mathrm{mils} & 3800 \mathrm{y} & 1900 \mathrm{y}\end{array}$

Carbon steel is susceptible to pitting corrosion and general corrosion in oxygenated water, but pitting and crevice factors are close to one at lower temperatures, so penetrations are similar to general corrosion. Carbon steel is resistant to stress corrosion cracking under the relatively benign conditions expected for the cask liners. While the SS/CS couple tends to promote corrosion of carbon steel, area factors will be similar, minimizing accelerations of localized corrosion.

(a) The cask liner wall thickness at the thinnest section (floor) is 0.75 in. $=750 \mathrm{mil}$. 


\subsection{INTRODUCTION}

The Three Mile Island (TMI-2) accident in 1979 resulted in a severely degraded core that included melted and unmelted fuel assembly materials. The rubble from the pressurized-water reactor (PWR) core was placed in stainless steel canisters and was moved to the Idaho National Engineering Laboratory (INEL) in 1986-1990 (Schmitt et al. 19,3). The canisters are currently stored in a pool at Test Area-North (TAN). The next planned action for management of the canisters is to place them in concrete casks with carbon steel

liners, ${ }^{2}$ where the canisters are expected to reside until a repository is available for final disposal.

The analysis reported here was conducted to evaluate the integrity of the stainless steel (SS) canisters and carbon steel (CS) cask liners. The analys is includes evaluation of both wet (aqueous) and dry (air) modes of storage. Mechanisms were evaluated that include general wall thinning and localized generation of pinholes from corrosion.

\subsection{SCOPE OF THE ASSESSMENT}

Two components of the storage system were analyzed: the type $304 \mathrm{~L}$ SS canisters containing the TMI-2 core debris and the type 1020 carbon steel liners of the concrete casks.

The corrosion evaluations were scoped to address two aspects of degradation: 1) pinhole penetration of the canister wall or carbon steel liner, and 2) decrease in wall thickness to one-half of the original value due to uniform corrosion. Three conditions were defined for this assessment: 1) water at $20^{\circ} \mathrm{C}$, saturated with air, $2 \mathrm{ppm} \mathrm{Cl}^{-}$, inside the concrete casks; and 2) air at $20^{\circ} \mathrm{C}$, with two relative humidity (RH) levels: $10 \%$ and $40 \%$. Corrosion of the SS canisters was assessed for outer and inner surfaces. One of the three canister types (Fuel, Figure 1) has double containment. All of the canister interiors will be dried and backfilled with air or will remain flooded with water.

Corrosion mechanisms considered for local attack were: pitting, stress corrosion cracking, galvanic attack, and crevice corrosion. The mechanism considered for wall thinning was general corrosion. Microbially influenced corrosion (MIC) was excluded from the assessment due to hydrogen peroxide dosing of the water in the canisters and observations that suggested that MIC was not active (Schmitt et al. 1993).

\subsection{APPROACH TO THE ASSESSMENT}

The assessment involved identifying corrosion data that are considered relevant to the conditions expected to exist in the canisters and casks. In some cases, data at the relatively benign conditions specified for the analysis were not available; therefore, accessible data at somewhat more

(a) Other options are also being evaluated. 
aggressive conditions were utilized, resulting in a realistically conservative analysis.

This assessment faced challenges identical to those for other extended storage studies. The assessment had to either demonstrate thermodynamic stability of the affected materials over the expected storage time frame, or identify kinetic data that would serve as the basis for estimates of corrosion behavior of the storage system materials. For this assessment, thermodynamic considerations dictated that the stainless steel and carbon steel would be subject to corrosion; therefore a kinetic approach was necessary. The assessment requested was to estimate a) times for pinhole penetration of the stainless steel canisters and for loss of one-half of the wall thickness; b) estimates for pinhole and uniform penetration of the carbon steel liner after $50 \mathrm{y}$; and $\mathrm{c}$ ) times to throughwall pinhole penetration and loss of onehalf of the wall thickness for the carbon steel liner.

The assumption of constant saturated oxygen was imposed to simplify the analys is but, in reality, the cask and canister systems are assumed to be closed. Therefore, there will be a gradual decrease in oxygen in the water and air as reaction with the metals occurs. However, a $1,000 \mathrm{R} / \mathrm{hr}$ gamma field inside the canisters will generate radiolytic oxygen over the time frame that the field remains significant. The fuel canisters (Figure 1) have catalyst beds to recombine at least part of the radiolytic hydrogen/oxygen inventory, but the gamma fields will also cause radiolysis on the outer canister surfaces.

Are estimates of SS and CS durability over multimillenia credible? The durability of metals over time frames of centuries or millennia has been studied (Johnson and Francis 1980). Innumerable archaeological artifacts, metal meteorites, and native metal masses have survived for periods that are estimated, in some cases, to be several thousand years in a range of environments, including tombs, soils, sea water, caves, and buildings. While iron-based materials have generally been among the least durable, some iron objects have survived over several centuries and, in selected cases, for several millennia. Of particular interest are cases of iron cannon balls from sunken warships; those exposed to oxygenated sea water were severely degraded, while identical objects that were buried in sea sediments resided in conditions that became anoxic, resulting in minimal degradation. Iron objects in the King Tutankhamen tomb survived for more than three millennia with some rusting in an environment that was largely dry, but included periods of moisture incursions. Estimates of multimillenia durability of carbon steel cask liners in air gains some credibility from survival of the Tutankhamen iron artifacts in air. Analogues for the stainless steels do not exist among the ancient metals, but other high-integrity materials, e.g., copper, have survived for several millennia.

\subsection{CHARACTERISTICS OF THE TMI-2 FUEL DEBRIS}

The TMI-2 core degraded partially by oxidation of the Zircaloy cladding and partially by melting of metals and the oxide fuel pellets. Consequently, the debris in the canisters has a range of characteristics, depending on where it came from in the core. The debris is stored in three types of canisters, 
sorted according to size (Figure 1). In some cases, large sections of fuel assemblies and fuel rods are stored; in other cases, the rubble includes melted chunks and whole or fragmented fuel pellets. Some fragments are in the form of fines which were vacuumed from the reactor pressure vessel; they are collected on diatomaceous earth.

The TMI-2 core was in an early stage of exposure when the accident occurred in 1979. The exposure was 92 effective full power days and the core average burnup was $\sim 3000$ MWd/MTU. There were 177 PWR fuel assemblies in the core. The degraded core resided in the reactor pressure vessel unt il 1986 when canning operations began (Table 1). The last canisters were shipped to INEL in 1990. The fission product inventory was relatively small and much of the leachable species would have gone into the core water. Further removal of the leached species would have occurred when the TMI-2 water was removed from the canisters and replaced with TAN water. From the standpoint of the corrosion analysis it is assumed that fission product species are not a factor.

Section 2 of this report examines thermodynamic aspects of the carbon steel behavior. Materials, designs, and conditions are summarized in Section 3. Section 4 provides an estimate of the degree of degradation of the $304 \mathrm{~L}$ canisters during shipping and during wet storage at TMI-2 and at INEL. Estimated degradation of stainless steel canisters and carbon steel cask liners is given in Section 5 for wet and dry storage modes. Section 5 also includes calculational bases and rationales for the matrix of twelve material and environmental conditions. A concise discussion of the durability assessment appears in Section 6 . 


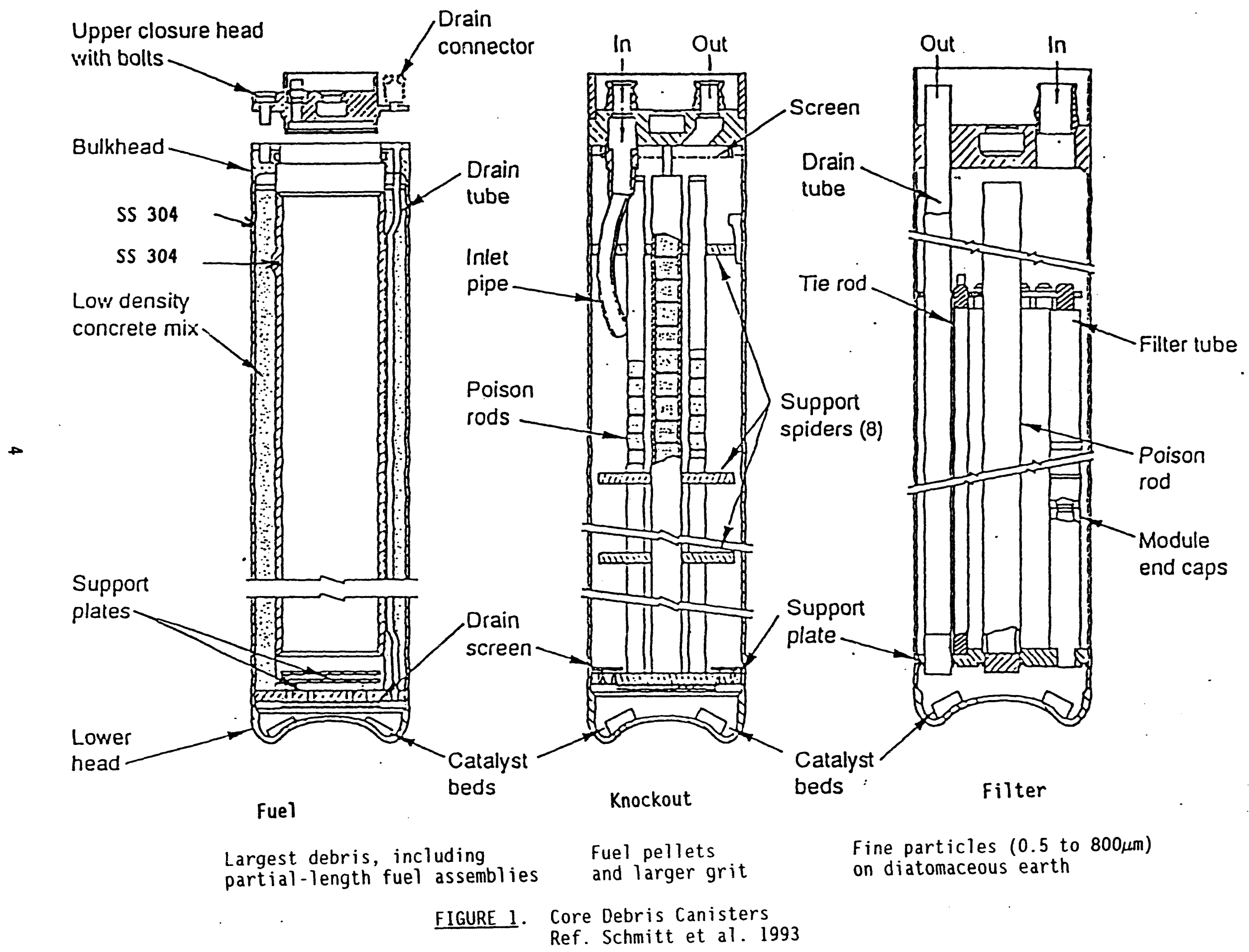


TABLE 1. Summary of TMI-2 Stainless Steel Canister Environments

\begin{tabular}{|c|c|c|c|c|}
\hline & $\begin{array}{c}1 \\
\text { TMI -2 Core Waste } \\
\end{array}$ & $\begin{array}{c}2 \\
\text { Canister Loading } \\
\text { and } \\
\text { Shipping to INEL } \\
\end{array}$ & $\begin{array}{c}3 \\
\text { Storage in TAN Pool } \\
\end{array}$ & Extended Storage \\
\hline $\begin{array}{l}304 L \text { SS Fabricated } \\
\text { to ASME PVC Sect. } \\
\text { VIII; long. \& girth } \\
\text { welds; no post-weld } \\
\text { HT }\end{array}$ & $\begin{array}{l}\text { TMI-2 degraded core } \\
\text { in pressure vessel. }\end{array}$ & $\begin{array}{l}\text { Canisters in RPV } \\
\text { and in spent fuel } \\
\text { pool. Reactor } \\
\text { water dosed with } \\
\mathrm{H}_{2} \mathrm{O}_{2} \text {. Canisters } \\
\text { dewatered; shipped } \\
\text { horizontal on rail } \\
\text { cars. }\end{array}$ & $\begin{array}{l}\text { Canisters filled } \\
\text { with DIW. Make-up } \\
\text { from TAN pool to } \\
\text { offset evaporation. }\end{array}$ & $\begin{array}{l}\text { Concrete cask, } \\
\text { mild steel liner. }\end{array}$ \\
\hline \multicolumn{2}{|c|}{1979} & 1986 & 1990 & 2000 \\
\hline $\begin{array}{l}\text { Canister Outside } \\
\text { Surface } \\
\text { Environments }\end{array}$ & & $\begin{array}{l}\text { TMI }-2 \text { core water: } \\
4500-4800 \mathrm{ppm} \mathrm{B} \\
\left(\mathrm{H}_{3} \mathrm{BO}_{3}\right) ; \mathrm{NaOH}(\mathrm{pH} \\
\text { control) } \mathrm{T}: 20-30^{\circ} \mathrm{C} ; \\
0.5 \text { to } 1.9 \mathrm{ppm} \mathrm{Cl}^{-} ; \\
\mathrm{O}_{2} \text {-saturated. }\end{array}$ & $\begin{array}{l}\text { TAN pool water: } \\
\text { T: } 20-25^{\circ} \mathrm{C} ; 2 \mathrm{ppm} \\
\mathrm{Cl}^{-} ; 0_{2} \text {-saturated }\end{array}$ & $\begin{array}{l}20^{\circ} \mathrm{C} \text { in water or } \\
\text { air. } 2{\mathrm{ppm} \mathrm{Cl}^{-} \text {in }} \mathrm{H}_{2} \mathrm{O} ; \mathrm{O}_{2} \text {-saturated. }\end{array}$ \\
\hline $\begin{array}{l}\text { Canister Inside } \\
\text { Surface } \\
\text { Environments }\end{array}$ & & $\begin{array}{l}\text { TMI-2 core water; } \\
10^{3} \mathrm{R} / \mathrm{hr} \text { gamma; } \\
0.5 \text { to } 1.9 \mathrm{ppm} \mathrm{Cl}^{-} ; \\
0_{2} \text {-saturated. Air } \\
\text { during shipping; } \\
\text { - } 13 \text { lb. TMI-2 } \mathrm{H}_{2} 0 \\
\text { left after } \\
\text { dewatering. }\end{array}$ & $\begin{array}{l}\text { TAN pool water: } \\
\mathrm{T}: \quad 20-25^{\circ} \mathrm{C} ; \mathrm{Cl}^{-} 2 \\
\text { ppm; } \mathrm{O}_{2} \text {-saturated }\end{array}$ & $\begin{array}{l}\text { options for SS } \\
\text { canister } \\
\text { interiors: } \\
\text { a) rinse in DIW; } \\
\text { dry } 100 \mathrm{hr} \text { at } \\
150^{\circ} \mathrm{C} \text { or } \\
\text { b) leave filled } \\
\text { with water. }\end{array}$ \\
\hline
\end{tabular}

DIW: deionized water

HT: heat treatment

RPV: reactor pressure vessel 


\subsection{THERMODYNAMIC BASIS}

When carbon steel is place in water, iron atoms from the metal enter the water by the anodic (electron-donating) reaction:

$$
\mathrm{Fe} \leftrightarrow \mathrm{Fe}^{++}+2 \mathrm{e}^{-}
$$

forming a solution of positively charged $\mathrm{Fe}^{++}$ions in the water and giving up two electrons. The electrons enter the metal and need to be removed by a cathodic (electron-accepting) reaction. There are a number of cathodic reactions that can take $p l a c e$ at the aquequs solution/metal interface. Two common reactions are: the oxygen reduction reaction

$$
\mathrm{O}_{2}+2 \mathrm{H}_{2} \mathrm{O}+4 \mathrm{e}^{-} \leftrightarrow 4(\mathrm{OH})^{-}
$$

and the hydrogen evolution reaction

$$
2 \mathrm{H}^{+}+2 \mathrm{e}^{-} \leftrightarrow \mathrm{H}_{2}
$$

Corrosion of iron (or any metal) in contact with an aqueous solution is electrochemical in nature. That is, it is accompanied by release of electrons according to Reaction 1 or a similar reaction, as demonstrated by the fact that the piece of iron acquires an electrochemical potential when immersed in water and that this potential can be readily measured using a voltmeter to determine the voltage between the metal and another reference metal immersed in the same body of water. The presence of the hydrogen evolution reaction is often indicated by bubbles of a gas rising from the corroding metal. The presence of the oxygen reduction reaction may be verified by checking the $\mathrm{pH}$ of the water. As may be seen from Reaction 2, the concentration of $(\mathrm{OH})^{-}$ ions in the water will increase, and the water's pH will increase as the reaction proceeds.

Further, as one would expect of any chemical or electrochemical reaction, Reactions 1 through 3 and other similar corrosion reactions are governed by laws of chemical equilibria, among them the law of mass action. As a result, these reactions may proceed from left to right, or vice versa, by applying an electrical potential to the electrode. Also, as seen from Reactions 1 and 2 , since they include $\mathrm{H}^{+}$and $(\mathrm{OH})^{-}$ions, one can draw plots of electrical potential of a corroding metal against the $\mathrm{pH}$ of water on which only certain reactions or reaction products are stable within particular regions of the plot. Such plots are complicated and difficult to calculate for real systems of impure metals corroding in water solutions containing many different ionic species, all of which might take part in reactions similar to those above. However, such plots can be made for the simple system of a single pure metal (such as iron) in contact with the purest electrolyte, water that does not contain any other impurity except dissolved oxygen or hydrogen. Such plots are called potential-pH, or Pourbaix, diagrams. Despite the theoretical nature of such diagrams and the simple metal-pure water systems for which they are plotted, they are of enormous practical importance. For example, most carbon steels are in effect nearly pure iron, containing not more than one weight percent of impurities. Carbon steels, therefore, behave 
nearly as pure iron, and their behavior under conditions of varying $\mathrm{pH}$ and dissolved oxygen content may be predicted, at least qualitatively, from the Pourbaix diagram for iron. This diagram is presented as Figure 2.

Illustrated in Figure 2 are the potential regions for Reaction 1 which are represented by the regions of potential more positive than those shown for lines 23, 13, and 24 (shown by circled numbers). Reactions 2 and 3 can occur only at potentials more negative than those shown for dotted lines $b$ and a, respectively. In other words, iron will only corrode in the region of potentials bounded by 1 ines 23,13 , and 24 on one side and 1 ine $b$ if the cathodic reaction is Reaction 3 , and by the region bounded by 1 ines 23,13 , and 24 , and line $a$ if the cathodic reaction is Reaction 2 . Also, between $\mathrm{pH}^{\prime} \mathrm{s}$ of 9 to 13.5, iron corrodes to form the oxide magnetite, $\mathrm{Fe}_{3} \mathrm{O}_{4}$, which generally retards the supply of dissolved oxygen and/or hydrogen ions to the metal surface. The metal then acquires passivity--in principle it is not immune to corrosion but it might acquire immunity because of the formation of a passive film of magnetite on the metal surface. Chloride ions are very small, have high mobility, and because of their negative charge, are attracted toward the positively charged corroding surface (positively charged, because it is shedding positively charged iron ions into the water). These chloride ions locally destroy passive films, even the very tight and dense films that form on stainless steels. The sites of film destruction become potential sites for pit initiation and growth.

In Figure 2, line a, representing the hydrogen evolution reaction, lies above lines 23,13 , and 24 for oxidation of iron. Thermodynamically, this placement dictates that iron is unstable in the presence of water over the entire $\mathrm{pH}$ range from -2 to 16 , and will corrode with hydrogen evolution. However, though this reaction is thermodynamically possible, the rates of the corrosion reactions are determined by kinetic factors, and often need to be determined empirically.

In summary, thermodynamic considerations indicate that corrosion of the carbon steel liners will proceed under conditions expected to exist during extended interim storage. 


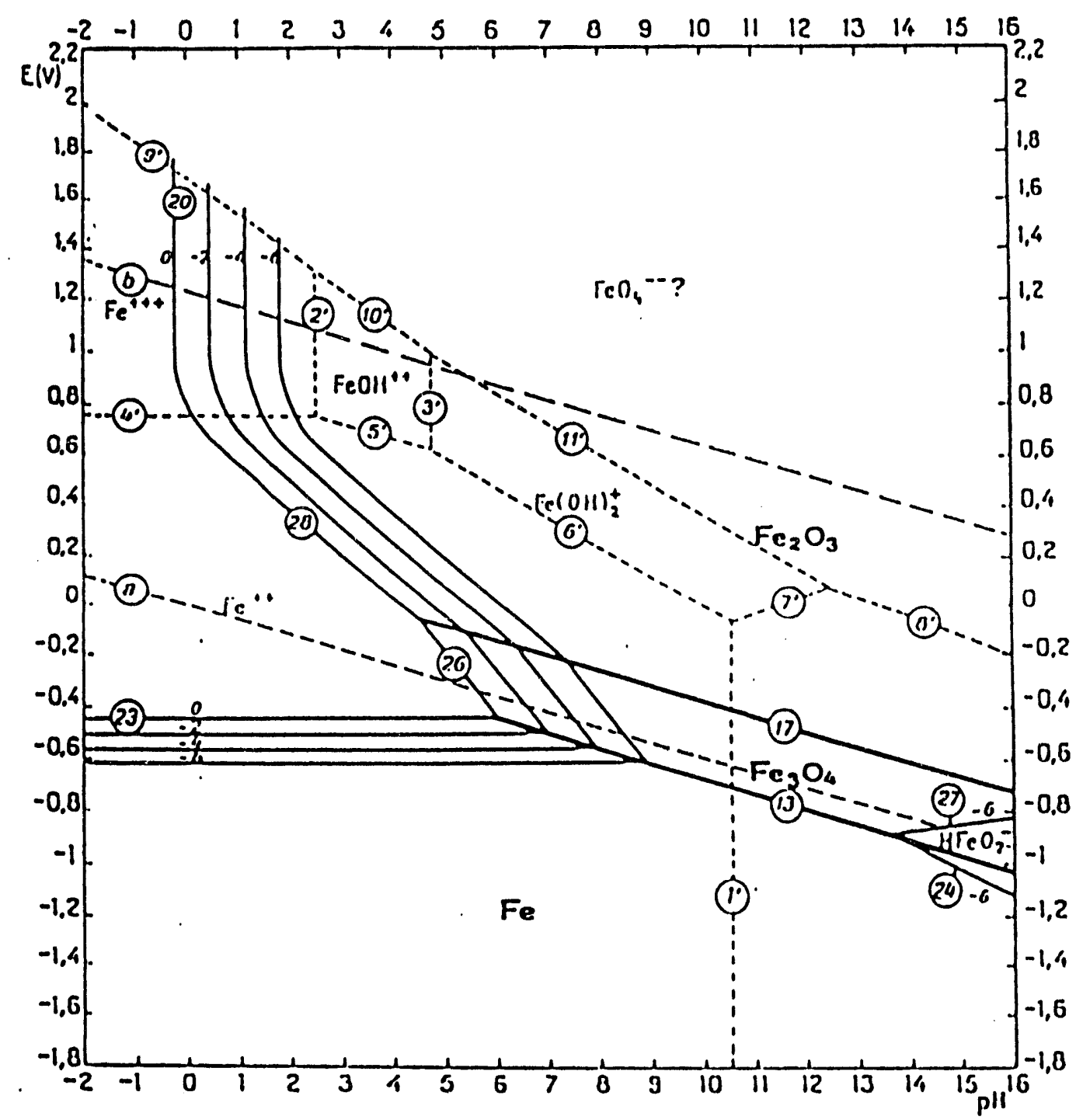

FIGURE 2. Potential pH Equilibrium Diagram for the System Iron Water at $25^{\circ} \mathrm{C}$ (considering as solid substances only $\mathrm{Fe}, \mathrm{Fe}_{3} \mathrm{O}_{4}$, and $\left.\mathrm{Fe}_{2} \mathrm{O}_{3}\right)$. Ref. Pourbaix, M. 1978. Atlas of Electrochemical Equilibration in Aqueous Solutions. McGraw-Hil1, pp. 315-318. 


\subsection{MATERIALS, DESIGNS, AND CONDITIONS}

It is essential to this materials evaluation to understand the properties and configurations of the materials that are to be assessed. This section provides a summary of these factors.

\subsection{MATERIALS}

The canister and storage cask materials are summarized in Table 2. Table 3 provides alloy compositions. The canisters were manufactured according to the 1983 ASME Boiler and Pressure Vessel Code, Section VIII, Division 1. The canisters have longitudinal and girth welds. There was no post-weld heat treatment. On one hand, the absence of the heat treatment will minimize sensitization of the stainless steel, but, on the other hand, the residual stresses of the $304 \mathrm{~L}$ stainless steel will remain at a high level, assumed to be near the yield strength.

The concrete storage casks include several materials (Table 2), but this analysis will focus on the carbon steel liner.

\subsection{DESIGNS}

There are three canister designs (Figure 1). Different ranges of debris sizes are stored in the three canisters as indicated in Figure 1 . The concrete cask configuration has not been finalized. Currently the concept involves a reinforced concrete cask with a carbon steel liner and carbon steel pipes that would house the stainless steel canisters.

\subsection{CONDITIONS}

The conditions that the canisters have been exposed to and are expected to be exposed to in the future are summarized in Table 1. Corrosion data applied to estimate durability of the TMI-2 canisters over the time frame 1986 through 2000 (Section 4) were taken from the same sources used for corrosion calculations beyond the year 2000 (Section 5). The results are summarized in the following sections. 
TABLE 2. Canister and Cask Materials and Dimensions ${ }^{(a)}$

\begin{tabular}{|c|c|c|c|c|}
\hline Component & Material & Dimensions & Fabrication Basis & Remarks \\
\hline TMI-2 canisters & $304 \mathrm{LSS}$ & $\begin{array}{l}1 \mathrm{ft} 2 \text { in. } 00 \\
11 \mathrm{ft} 8.4 \text { in. height } \\
0.25 \text { in. wall } \\
\text { thickness }\end{array}$ & ASME PVC Section VIII & $\begin{array}{l}\text { three canister designs } \\
\text { (see Figure 1) }\end{array}$ \\
\hline \multirow[t]{3}{*}{ concrete casks } & reinforced concrete & $\begin{array}{l}8 \mathrm{ft} 9 \text { in. } 00 \\
15 \mathrm{ft} 5.5 \text { in. height }\end{array}$ & & $\begin{array}{l}\text { exterior sealant on } \\
\text { concrete; A1 alloy } \\
\text { plate on cask lid; } \\
\text { carbon steel shield } \\
\text { plug }\end{array}$ \\
\hline & $\begin{array}{l}\text { carbon steel cask } \\
\text { liner, alloy ASTM } \\
\text { A516 Gr60 }\end{array}$ & $\begin{array}{l}\text { wall thickness: } 3 \text { in. } \\
\text { floor thickness: } \\
0.75 \text { in. }\end{array}$ & & \\
\hline & $\begin{array}{l}\text { carbon steel pipes; } \\
\text { alloy ASTM A53 GrB }\end{array}$ & $\begin{array}{l}16 \text { schedule } 40 \text { pipes } \\
16 \mathrm{in.} 00 \\
15.1 \mathrm{in.} 10 \\
12 \mathrm{ft} 10.5 \mathrm{in} \text {. height }\end{array}$ & & \\
\hline
\end{tabular}

(a) Schmitt et al. 1993 
TABLE 3. Composition of Carbon Steel Cask Liner and Stainless Steel Canister Materials ${ }^{(a)}$

\begin{tabular}{|c|c|c|c|c|c|c|c|c|c|c|c|c|c|c|c|}
\hline $\begin{array}{l}\text { Steel Allovs } \\
\text { ASTM A36 } \\
\text { (UNS K02600) }\end{array}$ & $\frac{C}{.26}$ & $\frac{P}{.04}$ & $\frac{\mathrm{S}}{.05}$ & $\mathrm{Mn}$ & $\underline{\mathrm{Si}}$ & \multicolumn{10}{|c|}{$\frac{\text { Other }}{.20 \mathrm{Cu} \text { (when Copper Steel is specified) }}$} \\
\hline $\begin{array}{l}\text { ASTM A516 gr. } 60 \\
\text { (UNS K02100) }\end{array}$ & $\begin{array}{l}.21 \\
\max \end{array}$ & $\begin{array}{l}.035 \\
\max \end{array}$ & $\begin{array}{l}.04 \\
\max \end{array}$ & $\begin{array}{l}.55- \\
.98\end{array}$ & .13 & & & & & & & & & & \\
\hline $\begin{array}{l}\text { ASTM A53 gr. B } \\
\text { (UNS K03005) }\end{array}$ & $\begin{array}{l}.30 \\
\max \end{array}$ & $\begin{array}{l}.05 \\
\max \end{array}$ & $\begin{array}{l}.06 \\
\max \end{array}$ & $\begin{array}{l}1.20 \\
\max \end{array}$ & & & & & & & & & & & \\
\hline $\begin{array}{l}\text { Stainless Steel Allovs } \\
\text { ASME SA 240-304L } \\
\text { (UNS S30403) }\end{array}$ & $\begin{array}{l}\mathrm{C} \\
.03 \\
\max \end{array}$ & $\mathrm{Cb} / \mathrm{Nb}$ & Co & $\begin{array}{l}\frac{C r}{18.00} \\
20.00\end{array}$ & $\mathrm{Cu}$ & $\frac{\mathrm{Mn}}{2.00}$ & Mo & $\mathrm{N}$ & $\frac{\mathrm{Ni}}{8.00}$ & $\frac{P}{.045}$ & $\frac{S}{.030}$ & $\frac{\mathrm{Si}}{1.00}$ & $\mathrm{Ta}$ & $\mathrm{Ti}$ & V \\
\hline $\begin{array}{l}308 \mathrm{~L} \\
\text { (Coated Electrode } \\
\text { for Stainless Steel) }\end{array}$ & $\begin{array}{l}0.019 \\
0.032\end{array}$ & 0.01 & $\begin{array}{l}0.03 \\
0.13\end{array}$ & $\begin{array}{l}19.81- \\
20.31\end{array}$ & $\begin{array}{l}0.03- \\
0.16\end{array}$ & $\begin{array}{l}1.56- \\
2.1\end{array}$ & $\begin{array}{l}0.02- \\
0.30\end{array}$ & 0.035 & $\begin{array}{l}9.82- \\
10.3\end{array}$ & $\begin{array}{l}0.016 \\
0.02\end{array}$ & $\begin{array}{l}0.004- \\
0.01\end{array}$ & $\begin{array}{l}0.34- \\
0.51\end{array}$ & 0.01 & $\begin{array}{l}0.001- \\
0.02\end{array}$ & $\begin{array}{l}0.064- \\
0.116\end{array}$ \\
\hline
\end{tabular}

(a) Schmitt et al. 1993 


\subsection{ESTIMATED TMI - 2 CANISTER DURABILITY: $1986-2000$}

This section addresses durability estimates for the TMI-2 canisters during loading and wet storage at TMI, shipping, and wet storage at INEL for the period 1986 to 2000 (see Table 1).

The corrosion assessments for the 1986 - 2000 time frame included consideration of both uniform and localized mechanisms. The exposure conditions for the type 304L canisters at TMI-2 and at INEL are summarized in Table 1, involving temperatures near $20-30^{\circ} \mathrm{C}, \mathrm{Cl}^{-} \sim 2 \mathrm{ppm}$, and $\mathrm{O}_{2}$-saturated water. Because the conditions in the time frame 1986 to 2000 are similar to conditions specified for the aqueous case beyond 2000 , the same corrosion data were used. The data and rationales appear on data sheets for matrices $A$ and $D$ that are shown in Table 4 for the evaluation of corosion beyond the year 2000.

From the Matrix $D$ data sheet, the general corrosion rate for $304 \mathrm{~L}$ SS in water is $0.012 \mathrm{mils} / \mathrm{y}$, applied over $14 \mathrm{y}$. Other corrosion phenomena in water are indicated to be nil in the same time frame, based on data in Section 5 , Matrix $A$ data sheet. The durability results in water are summarized below:

$\begin{array}{ll}\text { general corrosion } & 0.17 \mathrm{mils} \\ \text { stress corrosion cracking } & n i l \\ \text { pitting corrosion } & n i l \\ \text { galvanic corrosion } & n i l \\ \text { crevice corrosion } & n i l\end{array}$

A metallographic study of stainless steel components exposed in spent fuel pools for periods up to 15 y (Kustas et al. 1981) offers confirmatory evidence for the results summarized above. Subject to uncertainties in interpreting metallographic sections on high-integrity materials, the sections suggest that significant localized corrosion was absent, except for occasional mild intergranular corrosion near welds on 304 SS, where sensitization can occur.

Another study (Bruemmer and Johnson 1983) offers a basis to judge effects of welding on sensitization of the $304 \mathrm{~L}$ canisters. In the study, type $304 \mathrm{~L}$ SS was subjected to a $625^{\circ} \mathrm{C} / 24 \mathrm{hr}$ heat treatment; three type $304 \mathrm{SS}$ materials were subjected to the same thermal conditions (Bruemmer and Johnson 1983). Degrees of sensitization for the four materials were compared using electrochemical potentiokinetic reactivation (EPR) measurements. The EPR values varied from 1.4 Coulombs per square centimeter $\left(\mathrm{C} / \mathrm{cm}^{2}\right)$ for $304 \mathrm{~L}$ material to $35.2 \mathrm{C} / \mathrm{cm}^{2}$ for the most sensitized 304 material. For unsensitized material the EPR values would be 0.0 to $0.5 \mathrm{c} / \mathrm{cm}^{2}$. The thermal treatment used in the study is more severe than is likely to occur in welding. The study was conducted in oxygen-saturated water with $15 \mathrm{ppm} \mathrm{Cl}^{-}$at $32^{\circ} \mathrm{C}$. Absence of cracking on "sensitized" type 304L specimens in the study strongly suggests that weld sensitization will not promote SCC of the $304 \mathrm{~L}$ canisters. The 
influence of stress in the study also mitigates prospects that SCC will occur. Residual stresses in the unannealed canisters are assumed to be near yield stresses, in lieu of specific evidence. In the referenced test series, no cracking occurred if the stress level was below $180 \%$ of the yield stress. The combination of low levels of weld-induced sensitization and stress levels below the expected threshold for SCC suggests that SCC of the type 304L TMI-2 canisters will be nil. 


\subsection{ESTIMATED TMI-2 CANISTER AND LINER DEGRADATION BEYOND 2000}

Results of corrosion assessments for extended interim storage of the TMI-2 canisters and related behavior of the steel cask liners are summarized in Table 4. The matrix addresses 304L SS and 1020 CS in three environments and includes consideration of general and localized corrosion, resulting in twelve data fields, A through $L$. Table 4 is followed by summaries that include conditions and rationale for corrosion assessments in each data field (Matrices). The term pinhole penetration is defined as a small hole that penetrates completely through the canister wall or the carbon steel liner. The pinhole can occur by several corrosion mechanisms, including pitting, stress corrosion cracking, or crevice corrosion.

The requested assessment included definition of the time to $50 \%$ loss of strength. This was interpreted to be represented by $50 \%$ wall 10 ss by uniform corrosion ( $50 \%$ loss in Table 4 ). The wall thinning is assumed to occur from the outer canister surfaces. The fuel canisters have double containment

(Figure 1). The canisters will either be dried and filled with air or will remain filled with water as they are placed in extended interim storage. 
IABLE 4. Summary of Corrosion Estimates ${ }^{(a)}$ Beyond $2000 A D$

\begin{tabular}{|c|c|c|c|}
\hline \multirow[b]{2}{*}{ Materials } & \multicolumn{3}{|c|}{ Environment } \\
\hline & $\mathrm{H}_{2} \mathrm{O} 20^{\circ} \mathrm{C}$ & $\mathrm{Air}+10 \% \mathrm{RH}$ & $\mathrm{Air}+40 \% \mathrm{RH}$ \\
\hline $\begin{array}{l}304 \text { SS canisters } \\
\text { (pinholes) }\end{array}$ & \begin{tabular}{ll}
\multicolumn{2}{c}{ Matrix A } \\
penetration by \\
pitting: \\
scc: & nil \\
crevice corrosion: & nil \\
galvanic corrosion: & nil \\
\end{tabular} & \begin{tabular}{ll}
\multicolumn{2}{c}{ Matrix B } \\
penetration by \\
pitting: \\
scc: & nil \\
crevice corrosion: & nil \\
galvanic corrosion: & nil \\
\end{tabular} & \begin{tabular}{ll}
\multicolumn{2}{c}{ Matrix $\mathrm{C}$} \\
penetration by \\
pitting: & nil \\
scc: & nil \\
crevice corrosion: & nil \\
galvanic corrosion: & nil \\
\end{tabular} \\
\hline $\begin{array}{l}304 \text { SS canisters } \\
\text { ( } 50 \% \text { wall } \\
\text { thickness loss) }\end{array}$ & $\begin{array}{l}\text { Matrix D } \\
\text { wall thinning: } 4600 \mathrm{y} \\
\end{array}$ & $\begin{array}{c}\text { Matrix E } \\
\text { wall thinning: } 11,500 \mathrm{y}\end{array}$ & $\begin{array}{c}\text { Matrix F } \\
\text { wall thinning: } 11,500 \mathrm{y}\end{array}$ \\
\hline $\begin{array}{l}\text { carbon steel cask } \\
\text { liners } \\
\text { (pinholes) }\end{array}$ & $\begin{array}{l}\text { Matrix G } \\
\text { penetration by } \\
\text { pitting: } 50 \text { y }-50 \text { mils } \\
\text { scc: through-wall } 750 \text { y } \\
\text { crevice corrosion: } \quad-50 \mathrm{mils} \\
\text { galvanic corrosion: } \quad \text { nil } \\
\end{array}$ & $\begin{array}{l}\text { Matrix H } \\
\text { penetration by } \\
\text { pitting: } 50 \text { y }-5 \mathrm{mils} \\
\text { through-wall: } 7500 \text { y } \\
\text { scc: } \quad \text { nil } \\
\text { crevice corrosion: }>7500 \text { y } \\
\text { galvanic corrosion: nil }\end{array}$ & $\begin{array}{l}\text { Matrix I } \\
\text { penetration by } \\
\text { pitting: } 50 \text { y }-10 \text { mils } \\
\text { through-wall: } 3800 \text { y } \\
\text { scc: } \\
\text { crevice corrosion: }>3800 \text { y } \\
\text { galvanic corrosion: nil }\end{array}$ \\
\hline $\begin{array}{l}\text { carbon steel cask } \\
\text { liners } \\
\text { ( } 50 \% \text { wall } \\
\text { thickness loss) }\end{array}$ & $\begin{array}{ll} & \text { Matrix J } \\
\text { wall } & \\
\text { thinning: } & 50 \text { y }-50 \mathrm{mils} \\
& 50 \% \text { loss }-375 \text { y }\end{array}$ & $\begin{array}{l}\text { Matrix } \mathrm{K} \\
\text { wall } \\
\text { thinning: } 50 \text { y }-5 \mathrm{mils} \\
50 \% \text { loss }-3800 \text { y }\end{array}$ & $\begin{array}{l}\text { Matrix L } \\
\text { wall } \\
\text { thinning: } 50 \text { y }-10 \mathrm{mils} \\
50 \% \text { loss }-1900 \text { y }\end{array}$ \\
\hline
\end{tabular}

(a) See following data sheets for data sources, corrosion rates and calculations, and rationales. The data sheets are coded to the matrix fields in Table 4. 


\section{Matrix A}

1. Scope: Type 304L stainless steel, pinhole penetration

2. Component: Core debris canister

3. Conditions: Water at $20^{\circ} \mathrm{C}$, gamma flux $1000 \mathrm{R} / \mathrm{h}, 2 \mathrm{ppm} \mathrm{Cl}, \mathrm{O}_{2}$-saturated

4. Data $\operatorname{Source}(s)$ :

A.1 Szklarska-Smialowska, Z. Pitting Corrosion of Metals. NACE, Katy, Texas, p. 243 \& 245.1986.

A.2 Bruemmer, S. M., and A. B. Johnson, Jr. "Effect of Chloride, Thiosulfate, and Fluoride Additions on the IG SCC Resistance of Type 304 Stainless Steel in Low Temperature Water." Proceedings of the International Symposium on Environmental Degradation of Materials in Nuclear Power System--Water Reactors. Published by National Association of Corrosion Engineers. American Nuclear Society, Myrtle Beach, South Carolina, pp. 571-580. 1983.

A.3 Metals Handbook, Ninth Edition, p. 977, 1987.

5. Corrosion Rate: $0 \mathrm{mil} / \mathrm{y}$

6. Corrosion Calculation: $(219 \mathrm{mil})^{(\mathrm{a})} \div(0 \mathrm{mil} / \mathrm{y})=$ infinite time to failure

7. Rationale: Pitting: On the basis of a critical evaluation of available literature, it is strongly believed that pitting of Type $304 \mathrm{~L}$ stainless steel will not occur under the specified conditions. A brief summary of the literature review that led to the above conclusion follows.

The most negative potential for nucleation of $p i t s{ }^{(b)}, E_{n p}$. on austenitic stainless steels measured in chloride bearing waters at room temperature is $+0.135 \mathrm{~V}$ SCE. Assuming the corrosion potential, Ecorr, to be no more positive than $-0.35 \mathrm{~V}$ SCE in aerated chloride solutions of neutral $\mathrm{pH}(\mathrm{pH}=6$ to 9$)$, the potential will have to be raised by 0.135 $(-0.350)=0.485 \mathrm{~V}$ for pitting to occur. Usually pitting is initiated when points on a stainless steel surface become enriched in chloride ions $\left(\mathrm{Cl}^{-}\right)$, and the chromium-rich oxide film on the surface is locally destroyed. Conditions that favor pit initiation are high temperatures, high chloride concentration, low pH values, the presence of deposits or debris on the metal surface, oxygen impoverishment, and stagnant conditions (A.1). In the case of the TMI-2 canisters, the neutral pH of

(a) The general wall thickness is $250 \mathrm{mil}$; the bottom head thickness is $219 \mathrm{mil}$, representing the thinnest wall section.

(b) See Section 2: THERMODYNAMIC BASIS, for a discussion of corrosion terms and basics. 
water, the very low halide concentrations $\left(2 \mathrm{ppm} \mathrm{Cl}{ }^{-}\right)$, and the presence of oxygen in water (saturated with air, hence containing about 8 ppm dissolved oxygen) are all factors that do not favor pit initiation and growth. Factors that would encourage pitting are the stagnant water and gamma radiation. Gamma radiation of the anticipated magnitude ( 1000 $\mathrm{R} / \mathrm{h}$ ) is expected to make Ecorr more positive by not more than $0.1 \mathrm{~V}$, since literature data (A.1) indicate that a radiation level of $10^{6} \mathrm{R} / \mathrm{h}$ leads to a potential change of $+150-200 \mathrm{mV}$ in low chloride (7 ppm Cl) water. The anticipated increase in Ecorr will raise it to a level which will still be far below $E_{\text {np }}$. On the other hand, the rise of Ecorr is due to generation of oxidizing species in the solution. Since initiation and propagation of pits is due to oxygen depletion at pitting sites, the presence of radiation will tend to counteract oxygen depletion. Finally, no documented instances of pitting of $18 \mathrm{Cr}-\mathrm{Ni}$ stainless steels have been discovered for aqueous solutions at chloride contents of below 100 ppm.

Stress Corrosion Cracking: Types 304 and 304L SS were subject to sensitizing heat treatments and then were tested at constant axial load in aerated DIW with ranges of $\mathrm{Cl}^{-}, \mathrm{F}^{-}$, and $\mathrm{S}_{2} \mathrm{O}_{3}{ }^{2}$. No cracking was observed, even for moderately sensitized specimens in water with $15 \mathrm{ppm}$ $\mathrm{Cl}^{-}$if the applied stress was less than $180 \%$ of yield (A.2).

Crevice Corrosion: The crevice factor for carbon steel at $50^{\circ} \mathrm{C}$ in Tuff groundwater was $\sim 1$ (A.3). The crevice factor for stainless steel is not expected to be substantially different.

Galvanic: Galvanic couple effects are not expected to be of concern for 304L stainless steel; the material is noble to carbon steel and would not be expected to preferentially corrode. 


\section{Matrix B}

1. Scope: Type 304L stainless steel, pinhole penetration

2. Component: Core debris canister

3. Conditions: $20^{\circ} \mathrm{C}$, air at $+10 \% \mathrm{RH}$, gamma flux $1000 \mathrm{R} / \mathrm{h}$

4. Data Source(s):

B.1 Dean, S. W., and T. S. Lee, eds. Degradation of Metals in the Atmosphere. ASTM STP 965, 1987 (Pitting Data).

B.2 Baboian, R., et al., eds. Galvanic and Pitting Corrosion. ASTM STP 576, 1.976 (Galvanic Data).

B.3 Laque, F. L., and H. R. Copson. Corrosion Resistance of Metals and Alloys. 2nd ed. Reinhold Puhlishing Corp. 1963.

B.4 Fontana, M. G., and N. D. Greene. Corrosion Engineering. 2nd ed. McGraw-Hill Book Co., 1978 (Crevice Data).

B.5 Behavior of Stressed and Unstressed $304 \mathrm{~L}$ Specimens in Tuff Repository Environmental Conditions. UCRL-91804, Lawrence Livermore National Laboratory Report, November 1984 (SCC Data).

5. Corrosion Rate: $0 \mathrm{mil} / \mathrm{y}$

6. Corrosion Calculation: Time to through-wall penetration for nominal wall thickness, bottom head $=219 \mathrm{mils}$

$(219 \mathrm{mils}) \div(0 \mathrm{mil} / \mathrm{y})=$ infinite time to failure

7. Rationale: Pitting - See Matrix A rationale for discussion of pitting on 304L stainless steel. Long-term (26-y) atmospheric studies conducted on type $304 \mathrm{~L}$ in a marine environment 250 meters from the ocean at Kure Beach test sites in North Carolina yielded corrosion rates of $<0.4$ mpy. Pitting and crevice corrosion are localized forms of corrosion that are accelerated by the presence of halides such as $\mathrm{Cl}^{-}$in the environment, and the levels of $\mathrm{Cl}^{-}$are high in an atmospheric marine environment. Atmospheric marine environments present a more aggressive environment for the material than the canister environment, due to variable humidity conditions, variable temperature conditions, and variable amounts of atmospheric pollutants. The corrosion rate for the $304 \mathrm{~L}$ in the aggressive environment remained low over a long period of study, so it is reasonable to assume that the material would exhibit even lower rates of corrosion in long term usage in a more benign TMI-2 canister environment. This approach using atmospheric corrosion data has been supported by reports such as UCRL-53449 "Containment Barrier Metals for High-Level Waste Packages in a Tuff Repository" by Russell et. al. dated October 12, 1983. It is noted by Laque and Copson (B.3) that if the relative humidity remains below $30 \%$ for the environment in question, the 
corrosion of most metals is negligible. They also mention that the surface should be kept reasonably clean of hygroscopic "dirt" which can cause corrosion even at $20 \%$ relative humidities.

Crevice - Crevice corrosion can arise from a difference in oxygen concentration leading to a differential oxygen cell effect. This effect is more pronounced for areas under water droplets or dirt, so at the low relative humidity conditions this type of corrosion is not expected to contribute substantially to the corrosion rates.

Stress Corrosion Cracking - Stress corrosion cracking requires three crucial conditions to be satisfied in order for the material to crack in the environment in question. These three conditions are a susceptible microstructure, an applied or residual stress, and corrosive environment. There is evidence that the microstructure has not been sensitized to the point of making the material susceptible to SCC (Bruemmer and Johnson 1983), and the environment at $20^{\circ} \mathrm{C}$ is benign regarding initiation of SCC (see Matrix A rationale and Section 4.0).

Galvanic - Galvanic couple effects are not expected to be of concern for $304 \mathrm{~L}$ stainless steel; the material is noble to carbon steel and would not be expected to preferentially corrode. 


\section{Matrix C}

1. Scope: Type 304L stainless steel, pinhole penetration

2. Component: Core debris canister

3. Conditions: $20^{\circ} \mathrm{C}$, a ir at $40 \% \mathrm{RH}$, gamma flux $1000 \mathrm{R} / \mathrm{h}$

4. Data Source(s):

- See references for Matrix A

C.1 Dean, S. W., and T. S. Lee, eds. Degradation of Metals in the Atmosphere. ASTM STP 965, 1987 (Pitting Data).

C.2 Baboian, R., et al., eds. Galvanic and Pitting Corrosion. ASTM STP 576, 1976 (Galvanic Data).

C.3 LaQue, F. L., and H. R. Copson. Corrosion Resistance of Metals and Alloys. 2nd ed. Reinhold Publishing Corp. 1963.

C.4 Fontana, M. G., and N. D. Greene. Corrosion Engineering. 2nd ed. McGraw-Hill Book Co., 1978 (Crevice Data).

C.5 Behavior of Stressed and Unstressed 304L Specimens in Tuff Repository Environmental Conditions. UCRL-91804, Lawrence Livermore National Laboratory Report, November 1984 (SCC Data).

5. Corrosion Rate: $0 \mathrm{mil} / \mathrm{y}$

6. Corrosion Calculations: Time to through-wall penetration nominal wall thickness bottom head $=219 \mathrm{mils}$

$(219 \mathrm{mils}) \div(0 \mathrm{mil} / \mathrm{y})=$ infinite time to failure

7. Rationale: Pitting - See Matrix B rationale.

Crevice - See Matrix B rationale.

Stress Corrosion Cracking - See Matrix B rationale.

Galvanic - See Matrix B rationale. 


\section{Matrix D}

1. Scope: Type $304 \mathrm{~L}$ stainless steel, $50 \%$ wall thickness loss

2. Component: Core debris canister

3. Conditions: $20^{\circ} \mathrm{C}$, Air-Saturated Water (dissolved oxygen $\sim 8 \mathrm{ppm}$ ), gamma flux $1000 \mathrm{R} / \mathrm{h}, 2 \mathrm{ppm} \mathrm{Cl}$

4. Data Source(s):

D.1 McCright, R. D., et al. "Selection of Candidate Canister Materials for High Level Nuclear Waste Containment in a Tuff Repository." Corrosion '84, Paper 198, April 2-6, 1984, New Orleans, Louisiana.

D.2 Weiss, H., et al. Metallurgical Analys is of a $304 \mathrm{~L}$ Stainless Steel Canister from the Spent Fuel Test -.. Climax. UCID-20436, Lawrence Livermore National Laboratory Report, April 1985.

5. Corrosion Rate: unirradiated - $0.01 \mathrm{mil} / \mathrm{y}$ ( 1 out of 3 coupons) $<0.005 \mathrm{mil} / \mathrm{y}$ (2 out of 3 coupons), weight loss detection limit (D.1)

irradiated $\left(3 \times 10^{5} \mathrm{rad} / \mathrm{hr}\right)-0.012 \mathrm{mil} / \mathrm{y}(\mathrm{D} .1)$

6. Corrosion Calculations: Time to $50 \%$ wall thickness loss

$(219 / 2 \mathrm{mil}) \div(2 \times 0.012 \mathrm{mil} / \mathrm{y})=4600$ y (rounded) (corrosion from ID and OD surfaces)

7. Rationale: The unirradiated specimen corrosion rates represent measured uniform corrosion rates in tuff groundwater at $100^{\circ} \mathrm{C}$ for 1000 -hour test exposures. The irradiated specimen corrosion rates represent measured rates in tuff groundwater at $105^{\circ} \mathrm{C}$ for 2 -month test exposures. The tuff groundwater composition is a relatively benign environment with a $\mathrm{Cl}^{-}$ concentration of $7.5 \mathrm{ppm}$ (as compared to the 2.0-2.5 ppm level in the TAN water). A complete breakdown of the water composition is given in data source 0.1 . The test environments are aggressive when compared to the reference environment for this study, due to the increased corrosion rate that can be expected from the increase in temperature. This is also the case for the higher radiation levels used in the test cited above when compared to the radiation levels at the surface of the fuel debris canisters. The corrosion rates will be very conservative due to the discrepancy between test conditions cited in the above reference and expected conditions for the TMI-2 fuel canisters with respect to temperature and radiation levels.

Described in data source D.2, the metallurgical analys is of a $304 \mathrm{~L}$ canister after it was used to store spent fuel from Turkey Point Unit \#3 reactor in a high level nuclear waste repository demonstration in climax granite. The storage configuration was essentially the same as the proposed configuration for the TMI-2 waste canisters: a $304 \mathrm{~L}$ canister 
used to contain the waste, surrounded by a carbon steel liner. Water entered the waste package between the carbon steel liner and the $304 \mathrm{~L}$ canister because of a crack in the carbon steel liner. From temperature measurements by thermocouples on the liner and the canister, the water was estimated to be present for approximately 3 years and the water contained from 6.9 to $160 \mathrm{mg} / \mathrm{L} \mathrm{Cl}^{-}$. The report stated that the canister material suffered no observable corrosion or cracking for the 3-year period. This environment is also more aggressive due to higher radiation levels of the Turkey Point spent fuel assemblies, the associated higher temperatures, and higher $\mathrm{Cl}^{-}$concentrations. 
Matrix

1. Scope: Type 304L stainless steel, $50 \%$ wall thickness loss

2. Component: Core debris canister

3. Conditions: $20^{\circ} \mathrm{C}, \mathrm{Air}+10 \% \mathrm{RH}$, gamma flux $1000 \mathrm{R} / \mathrm{h}$

4. Data Source(s):

E.1 Russe1l, et al. Containment Barrier Metals for High-Level Waste Packages in a Tuff Repository. UCRL-53449, Lawrence Livermore National Laboratory Report, October 1983.

E.2 Laque, F. L., and H. R. Copson. Corrosion Resistance of Metals and Alloys. 2nd ed. Reinhold Publishing Corp., 1963.

E.3 Effect of Ionizing Radiation On Moist Air Systems. UCRL-97936, Lawrence Livermore National Laboratory Report, December 1987.

5. Corrosion Rate: $0.005 \mathrm{mil} / \mathrm{y}(\mathrm{E} .1)$

6. Corrosion Calculation: Time to $50 \%$ wall thickness loss

$(219 / 2 \mathrm{mil}) \div(2 \times 0.005 \mathrm{mil} / \mathrm{y})=11,500 \mathrm{y}$ (corrosion from ID and OD surfaces)

7. Rationale: The above corrosion rates are based on 304 SS atmospheric corrosion rates during a 5-year exposure at an industrial site in the United Kingdom with air pollution controls and a mean temperature of $15^{\circ} \mathrm{C}$. The uncertainty associated with basing the corrosion rates on these data stem from the temperature fluctuations, humidity fluctuations, and a low but variable amount of atmospheric pollutants. The specimens were not subject to a radiation field, but the radiation flux in moist air is expected to result in nitric acid formation. Stainless steel is known to passivate in the presence of nitric acid, so the corrosion rate is not expected to increase. It is noted by Laque and Copson (E.2) that if the relative humidity remains below $30 \%$, general corrosion of most metals is negligible. 


\section{Matrix F}

1. Scope: Type 304 L stainless steel, $50 \%$ wall thickness loss

2. Component: Core debris canister

3. Conditions: $20^{\circ} \mathrm{C}$, Air at $40 \% \mathrm{RH}$, gamma flux $1000 \mathrm{R} / \mathrm{h}$

4. Data Source(s):

F.1 Russell, et al. Containment Barrier Metals for High-Level Waste Packages in a Tuff Repository. UCRL-53449, Lawrence Livermore National Laboratory Report, October 1983.

F.2 LaQue, F. L., and H. R. Copson. Corrosion Resistance of Metals and Alloys. 2nd ed. Reinhold Publishing Corp., 1963.

F.3 Effect of Ionizing Radiation On Moist Air Systems. CRL-97936, Lawrence Livermore National Laboratory Report, December 1987.

5. Corrosion Rate: $0.005 \mathrm{mil} / \mathrm{y}(\mathrm{F.1})$

6. Corrosion Calculations: Time to $50 \%$ wall thickness loss

$(219 / 2 \mathrm{mil}) \div(2 \times 0.005 \mathrm{mil} / \mathrm{y})=11,500$ y (corrosion from ID and OD surfaces

7. Rationale: The above corrosion rates are based on 304 SS atmospheric corrosion rates during a 5-year exposure at an industrial site in the United Kingdom with air pollution controls, with a prevailing temperature of $15^{\circ} \mathrm{C}$. The uncertainty associated with basing the corrosion rates on these data stem from the temperature fluctuations, humidity fluctuations, and a low but variable amount of atmospheric pollutants. The specimens were not subject to a radiation field, but the radiation flux in moist air is expected to result in nitric acid formation. Stainless steel is known to passivate in the presence of nitric acid, so the corrosion rate is not expected to increase. 
Matrix G

1. Scope: Type 1020 carbon steel, pinhole penetration

2. Component: Cask liner

3. Conditions: $20^{\circ} \mathrm{C}$, air-saturated water (dissolved oxygen $\sim 8 \mathrm{ppm}$ ), gamma flux $1000 \mathrm{R} / \mathrm{h}, 2 \mathrm{ppm} \mathrm{Cl}$.

4. Data Source(s):

G.1 Pourbaix, M. Atlas of Electrochemical Equilibria in Aqueous Solutions. NACE, Houston, Texas, p. 313. 1974.

G.2 Fontana, M. G., and N. D. Greene. Corrosion Engineering. McGrawHi11, P. 161. 1978.

G.3 Szklarska-Smialowska, Z. Pitting Corrosion of Metals. Houston, Texas, p. 203. 1986.

G.4 Parkins, R. N. "Stress Corrosion Cracking of Low Carbon Steels." In Fundamental Aspects of Stress Corrosion Cracking. Eds. R. W. Staehle, A. J. Forty, and D. Van Rooyen, pp. 361-373. 1969.

G.5 Galvanic Metals Handbook, p. 977.

G.6 Fontana and Greene, ibid, p. 35 .

5. Corrosion Rate: $1 \mathrm{mil} / \mathrm{y}$

6. Corrosion Calculations:

a) penetration at $50 \mathrm{y}:(1 \mathrm{mil} / \mathrm{y}) \times(50 \mathrm{y})=50 \mathrm{mils}$

b) time to complete penetration: $(750 \mathrm{mil}) \div(1 \mathrm{mil} / \mathrm{y})=750 \mathrm{y}$

7. Rationale: ASTM A516 gr 60 steel (C $0.21 \% \max$, Mn 0.55-0.98\%, Si 0.13 $0.45 \%)$, the cask liner material is similar in composition to SAE 1020 stee] (C $0.18-0.23 \%$, Mn 0.30-0.60\%). It will have corrosion properties similar to other low-carbon $(<0.3 \% \mathrm{C})$ steels. Carbon steels in general will pit in waters containing halides (fluoride, chloride, bromide, and iodide) and under conditions where differential aeration cells (different concentrations of dissolved oxygen, as in the case of the outside and inside of a crevice or a gasket). However, a minimum concentration of a halide ion is necessary for these ions to undermine the protective oxide film that generally forms on steels in aqueous solutions at $\mathrm{pH}$ values between 6 and 13 . This film may be only a few atoms thick and not always visible. The halide ions, if in sufficient concentration, destroy the passive film locally, initiating a pit at the site. If the concentration is below the minimum, pitting does not occur, but the general corrosion rate might increase (G.3). The minimum chloride concentration for room-temperature aqueous solutions for 
pitting of iron is reported to be $11 \mathrm{ppm}$ at $\mathrm{pH} 0$ (acid solutions), 18 $\mathrm{ppm}$ at $\mathrm{pH} 5$ (near-neutral acid solutions), and $106 \mathrm{ppm}$ at $\mathrm{pH} 8.4$ (basic solutions). The $\mathrm{pH}$ of the storage water is expected to be near neutral, differential concentration cells are expected to be minimal due to the oxidizing effect of extant radiation of $1000 \mathrm{R} / \mathrm{h}$, also the chloride content (2 ppm) is well below that at which pitting will occur, even in acid solutions; therefore, pitting of carbon steel is expected to be minimal during storage. The expected pitting rate is estimated to be equal to the general corrosion rate, estimated to be no more than 1 mil/y (see Matrix J).

Stress Corrosion Cracking: Carbon steel is expected to be resistant to stress corrosion cracking under the relatively benign conditions expected for the cask liners (G.4).

Other concerns regarding pinhole penetration are 1) crevices under the dished end of canisters, and 2) galvanic effects at points of contact with the stainless steel canister. Crevice corrosion occurs from the cumulative effect of several phenomena occurring in crevices, including oxygen depletion because corrosion reactions within the crevice deplete oxygen, while the exterior supply is limited due to lack of circulation of the solution; a second phenomenon is acidification of the crevice solution because of hydrolys is of metal ions going into solution (e.g., $\mathrm{Fe}^{++}+2 \mathrm{H}_{2} \mathrm{O}=\mathrm{Fe}(\mathrm{OH})_{2}+2 \mathrm{H}^{+}$); a third phenomenon is migration of negatively charged $\mathrm{Cl}^{-2}$ ions into the crevice containing an excess of positively charged $\mathrm{H}^{+}$ions. Crevice corrosion is not expected to occur in the present case due to the small chloride concentrations of the cask environment and the presence of radiation at $1000 \mathrm{R} / \mathrm{h}$, causing radiolysis, which is expected to counteract effects of oxygen depletion. Galvanic effects (G.5) lead to corrosion when a corrosion resistant material is in electrical contact with a corrosion prone material. The usual result of galvanic corrosion is that the corrosion resistant material corrodes at an even lower rate than it would have when isolated, and the corrosion-prone material corrodes at a higher rate. The effect on rates is larger, the larger the area of the more noble metal. In the present case, galvanic effects are expected to be minimal because of the noncorrosive nature of the water, nearly equal areas of contact between relatively noble Type $304 \mathrm{~L}$ stainless steel canister and relatively more corrosion prone carbon steel, and the oxidizing effect of radiation. The radiation is expected to decrease the galvanic effect by raising the corrosion potential of both metals. Because stainless steel is easily polarized, galvanic effects on other metals often tend to be minimized. 


\section{Matrix $H$}

1. Scope: Type 1020 carbon steel, pinhole penetration

2. Component: Cask liner

3. Conditions: $20^{\circ} \mathrm{C}$, Air at $10 \% \mathrm{RH}$

4. Data Source(s):

H.1 Abbott, W. H. Unoublished Results. Private Communication, March 16, 1994, Battelle Columbus Laboratories.

5. Corrosion Rate: $0.1 \mathrm{mil} / \mathrm{y}(\mathrm{H} .1)$

6. Corrosion Calculations:
a) Penetration in $50 \mathrm{y}$ :
$(0.1 \mathrm{mil} / \mathrm{y}) \times(50 \mathrm{y})=5 \mathrm{mils}$
b) Time to through-wall penetration:
$(750 \mathrm{mil}) \div(0.1 \mathrm{mil} / \mathrm{y})=7500 \mathrm{y}$

6. Rationale: As described in Matrix K, the corrosion of carbon steel under the above conditions will be immeasurably small for exposures of a few years. Further, the corrosion will be of the uniform type and not of the pinhole type. This is so because, in view of available literature data, there is a minimum relative humidity below which corrosion of metals will not occur. The minimum RH is a function of temperature and contaminants in the air (minimum 50\% RH at $10 \mathrm{ppb} \mathrm{Cl}$ in air at room temperature). The reported rate from the data source for 1016 carbon steel $(0.1 \% \mathrm{C})$ is $0.2 \mathrm{mil} / \mathrm{y}$ in air of $70 \%$ $\mathrm{RH}$ and containing $10 \mathrm{ppb} \mathrm{Cl}$. We, therefore, assume a conservative rate of half of this rate, $0.1 \mathrm{mil} / \mathrm{y}$, for $10 \% \mathrm{RH}$ air at $20^{\circ} \mathrm{C}$ that does not contain chlorine or other contaminants. It is likely that the actual rate will be a fraction of this rate. 


\section{Matrix 1}

1. Scope: Type 1020 carbon steel, pinhole penetration

2. Component: Cask liner

3. Conditions: $20^{\circ} \mathrm{C}$, Air at $40 \% \mathrm{RH}$

4. Data Source(s):

I.1 Abbott, W. H. Unpublished Results. Private Communication, March 16, 1994, Battelle Columbus Laboratories.

5. Corrosion Rate: $0.2 \mathrm{mil} / \mathrm{y}$ (1.1)

6. Corrosion Calculations:

a) Penetration at $50 \mathrm{y}:(0.2 \mathrm{mil} / \mathrm{y}) \times(50 \mathrm{y})=10 \mathrm{mils}$

b) Time to through-wall penetration: $(750 \mathrm{mil})+(0.2 \mathrm{mil} / \mathrm{y})=3800 \mathrm{y}$

6. Rationale: See rationale for Matrix $\mathrm{H}$. Air with $40 \% \mathrm{RH}$ is expected to be slightly more aggressive than air with $10 \% \mathrm{RH}$; therefore, the corrosion rate was estimated to be $0.2 \mathrm{mil} / \mathrm{y}$. 


\section{Matrix $\mathrm{J}$}

1. Scope: Type 1020 carbon steel, 50\% wall thickness loss

2. Component: Cask liner

3. Conditions: $20^{\circ} \mathrm{C}$, Air-Saturated Water, gamma flux $1000 \mathrm{R} / \mathrm{h}, 2 \mathrm{ppm} \mathrm{Cl}$

4. Data Source(s):

J.1 Pourbaix, M. Atlas of Electrochemical Equilibration in Aqueous Solutions. McGraw-Hil1, pp. 315-318. 1978.

J.2 Glass, R. S., R. A. Van Konynenburg, and G. E. Overturf.

Corrosion Processes of Austenitic Stainless Steels and Copper-Base Materials in Gamma Irradiated Aqueous Solutions. UCRL-92941, pp. 1-15, September 1985.

5. Corrosion Rate: $1 \mathrm{mil} / \mathrm{y}$

6. Corrosion Calculation:
a) penetration at $50 \mathrm{y}$ :
$(1 \mathrm{mil} / \mathrm{y}) \times(50 \mathrm{y})=50 \mathrm{mils}$
b) time to $50 \%$ wall loss:
$(750 / 2 \mathrm{mil}) \div(1 \mathrm{mil} / \mathrm{y})=375 \mathrm{y}$

7. Rationale: Corrosion rates for carbon steel in aqueous solutions are a function of $\mathrm{pH}$ and dissolved oxygen content (J.1). The corrosion rates are small $(<0.3 \mathrm{mil} / \mathrm{y})$ for $\mathrm{pHs}$ between 9.5 and 12.5 , but progressively increase as the $\mathrm{pH}$ decreases below 9.5 or increases above 12.5. At pHs above 8.0 , the amount of oxygen in oxygen-saturated water $(8 \mathrm{ppm}$ at $25^{\circ} \mathrm{C}$ ) is sufficient to form a film of magnetite, $\mathrm{Fe}_{3} \mathrm{O}_{4}$, on the surface, and the corrosion rate is expected to be close to $0.1 \mathrm{mil} / \mathrm{y}$. At $\mathrm{pH}$ values up to $\mathrm{pH} 8$, the presence of oxygen will not bring about the passivation of the surface but instead give a higher corrosion rate, about $1 \mathrm{mil} / \mathrm{y}$. With radiation of $1000 \mathrm{R} / \mathrm{h}$, the potential will rise higher (J.2), probably by about $0.1 \mathrm{~V}$. At $\mathrm{pH}$ values above 8 , radiation will be beneficial in that it will improve the formation of a passive film, promoting low corrosion rates. The corrosion rates given above are based on data for distilled and potable waters with or without oxygen (J.1).

Crevice and galvanic effects are considered minimal for reasons presented in Matrix G. 


\section{Matrix K}

1. Scope: Type 1020 carbon steel, $50 \%$ wall thickness loss

2. Component: Cask liner

3. Conditions: $20^{\circ} \mathrm{C}$, air at $10 \% \mathrm{RH}$

4. Data Source(s):

K.1 Abbott, W. H. Unpublished Results, Private Communication, March 16, 1994, Battelle Columbus.

5. Corrosion Rate: $0.1 \mathrm{mil} / \mathrm{y}(K .1)$

6. Corrosion Calculations:
a) penetration at $50 \mathrm{y}$ :
$(0.2 \mathrm{mil} / \mathrm{y}) \times(50 \mathrm{y})=5 \mathrm{mils}$
b) time to $50 \%$ wall thickness loss:
$(750 / 2 \mathrm{mil}) \div(0.1 \mathrm{mil} / \mathrm{y})=3800 \mathrm{y}$

7. Rationale: The corrosion of metals in air is a function of relative humidity and the kind and amount of impurities present. The most corrosive impurities are nitrogen dioxide $\left(\mathrm{NO}_{2}\right)$, sulfur dioxide $\left(\mathrm{SO}_{2}\right)$, and chlorine $\left(\mathrm{Cl}_{2}\right)$. In the case of SAE 1020 (0.2 percent carbon), at $100 \mathrm{ppb}$ chloriiie in air, corrosion rates were $2 \mathrm{mil} / \mathrm{y}$ at $80 \% \mathrm{RH}, 0.2$ $\mathrm{mil} / \mathrm{y}$ at $70 \% \mathrm{RH}$, and immeasurably small at humidities of $50 \% \mathrm{RH}$ and lower over an exposure of two years. The corrosion rate of ASTM A515 gr. 60 carbon steel for the above conditions is conservatively estimated to be $0.1 \mathrm{mil} / \mathrm{y}$. 


\section{Matrix L}

1. Scope: Type 1020 carbon steel, $50 \%$ wall thickness loss

2. Component: Cask liner

3. Conditions: $20^{\circ} \mathrm{C}$, air at $40 \% \mathrm{RH}$

4. Data Source: See Matrix H and Rationale below.

5. Corrosion Rate: $0.2 \mathrm{mil} / \mathrm{y}$ maximum

6. Corrosion Calculation:
a) penetration at $50 \mathrm{y}:(0.2 \mathrm{mil} / \mathrm{y}) \times(50 \mathrm{y})=10 \mathrm{mils}$
b) time to $50 \%$ wall thickness 1oss: $(750 / 2 \mathrm{mil}) \div(0.2 \mathrm{mil} / \mathrm{y})=1900 \mathrm{y}$

7. Rationale: As explained in Matrix $\mathrm{H}$, corrosion rates for carbon stee 1 at $20^{\circ} \mathrm{C}$ and in air of $40 \% \mathrm{RH}$ will be negligibly small. They will, however, be larger than at $10 \% \mathrm{RH}$. As we conservatively estimated a rate of $0.1 \mathrm{mil} / \mathrm{y}$ for Matrix $\mathrm{H}$, a proportional estimate for the rate at $40 \% \mathrm{RH}$ is double the rate at $10 \% \mathrm{RH}$, or $0.2 \mathrm{mil} / \mathrm{y}$. 


\subsection{DISCUSSION}

The projection of materials behavior over centuries and millennia remains a challenging exercise. However, the demonstrated durability of numerous metals and alloys over long time periods (Johnson \& Francis 1980) lends some credibility to the assessment, particularly for a material with recognized corrosion resistance (Type 304L SS) exposed to relatively benign conditions. Estimated corrosion penetrations for carbon steel liners seem qualitatively consistent with the described condition of iron artifacts exposed in air for more than three millennia.

A major challenge in this assessment was to identify corrosion data that are fully relevant to the specified environmental regimes. For stainless steels at $20^{\circ} \mathrm{C}$ in relatively pure waters, corrosion rates are too low to be of practical concern for most applications and, therefore, have not been the subject of substantial study. Consequently, data from more aggressive regimes had to be adapted. The basis for the carbon steel corrosion assessment was approached similarly. Therefore, the projected degradation rates are likely to be conservative. Extrapolations, e.g., from higher to lower temperatures, could possibly have increased the relevancy, but some data (Robertson 1991) suggest that temperature effects for stainless steel corrosion become nil at lower temperatures, if the materials is passive.

Again, there is little incentive to measure carbon steel or stainless steel corrosion rates in pure air at $20^{\circ} \mathrm{C}$. Therefore, the principal long-term data sources are from atmospheric corrosion studies in air with some pollutants, with a range of temperatures, and humidity levels that at times may exceed the $10-40 \% \mathrm{RH}$ range. These assessments also are expected to provide conservative results.

There are several uncertainties, e.g., regarding the debris configurations inside the canisters that could promote occluded cell attack. Also, the scope of the effort did not permit in-depth consideration of effects of the radiation field on corrosion. However, some insights to radiation effects are available in the literature and do not portend large accelerations.

The higher corrosion rates for carbon steel will result in an inventory of iron oxides that will have substantial mobility, at least while oxygen levels are relatively high. Therefore, it should be anticipated that the stainless steel canisters may be coated with carbon steel corrosion products upon removal from the concrete casks.

The consequences of pinhole penetration of the SS canisters has not been considered in detail, but an expected minimal inventory of fission products inside the canisters, combined with slow transport through the pinhole suggests that pinhole penetrations would not result in substantial impacts to the environment inside the concrete casks.

The original work scope requested durability data in the form $x \pm y$ years. This is most readily accommodated if corrosion data are reported in the format 
$a \pm b \mathrm{mil} / \mathrm{y}$. However, this is not the general case, and such data were not available for the cases addressed in the assessment. An alternative approach would be to compare results from different but comparable data sets. However, as indicated earlier, data closely relevant to the relatively benign regimes are largely lacking. Extrapolation from somewhat more aggressive regimes suggests that the results are likely to be conservative, and this is perhaps a more practical and useful perspective than one based on an uncertainty band that has minimal quantitative justification. 


\subsection{REFERENCES}

Bruemmer, S. M., and A. B. Johnson, Jr. 1983. "Effect of Chloride, Thiosulfate, and Fluoride Additions on the IG SCC Resistance of Type 304 Stainless Steel in Low Temperature Water." Proceedings of the International Symposium on Environmental Degradation of Materials in Nuclear Power System-Water Reactors. Published by National Association of Corrosion Engineers. American Nuclear Society, Myrtle Beach, South Carolina. pp. 571-580.

Craig, B. D. 1991. Fundamental Aspects of Corrosio.. ilms in Corrosion Science. Plenum Press, New York, pp. 115. Note: conclusion regarding pitting also based on discussion with Z. Szklarska-Smialowska.

Johnson, Jr., A. B., and B. Francis. 1980. Durability of Metals from Archaeological Objects, Metal Meteorites, and Native Metals. PNL-3198, Pacific Northwest Laboratory, Richland, Washington.

Kustas, F. M., et al. 1981. Investigation of the Condition of Spent Fuel Pool Components. PNL-3513, Pacific Northwest Laboratory, Richland, Washington.

Robertson, J. 1991. "The Mechanisms of High Temperature Aqueous Corrosion of Stainless Steels." Corr. Sci., Vol. 32, pp. 443-465.

Schmitt, R. C., G. J. Quinn, and M. J. Tyacke. 1993. Historical Summary of the Three Mile Island Unit 2 Core Debris Transportation Campaign. DOE/ID10400, EG\&G, Idaho Falls, Idaho.

Note - References relevant to the corrosion calculations are provided on matrix data sheets in Section 5.0. 


\section{DISTRIBUTION}

No. of

Copies

\section{OFFSITE}

2 DOE/Office of Scientific and Technical Information

J. Palmer (5)

EG\&G Idaho, Inc.

P.0. Box 1625

Idaho Falls, ID 83415-2406

T. McDonald (5)

EG\&G Idaho, Inc.

P.0. Box 1625

Idaho Falls, ID 83415-2406
No. of

Copies

ONSITE

DOE Richland Operations office

G. M. McClure

34 Pacific Northwest Laboratory
A. B. Johnson, Jr. (10)
A. L. Lund
(5)
S. P. Pednekar (5)
S. G. Pitman
R. E. Westerman
$M$. E. Cunningham
R. J. Guenther
E. R. Gilbert
M. D. Freshley
R. E. Einziger
J. L. Ethridge
Publishing Coordination
Technical Report Files (5) 

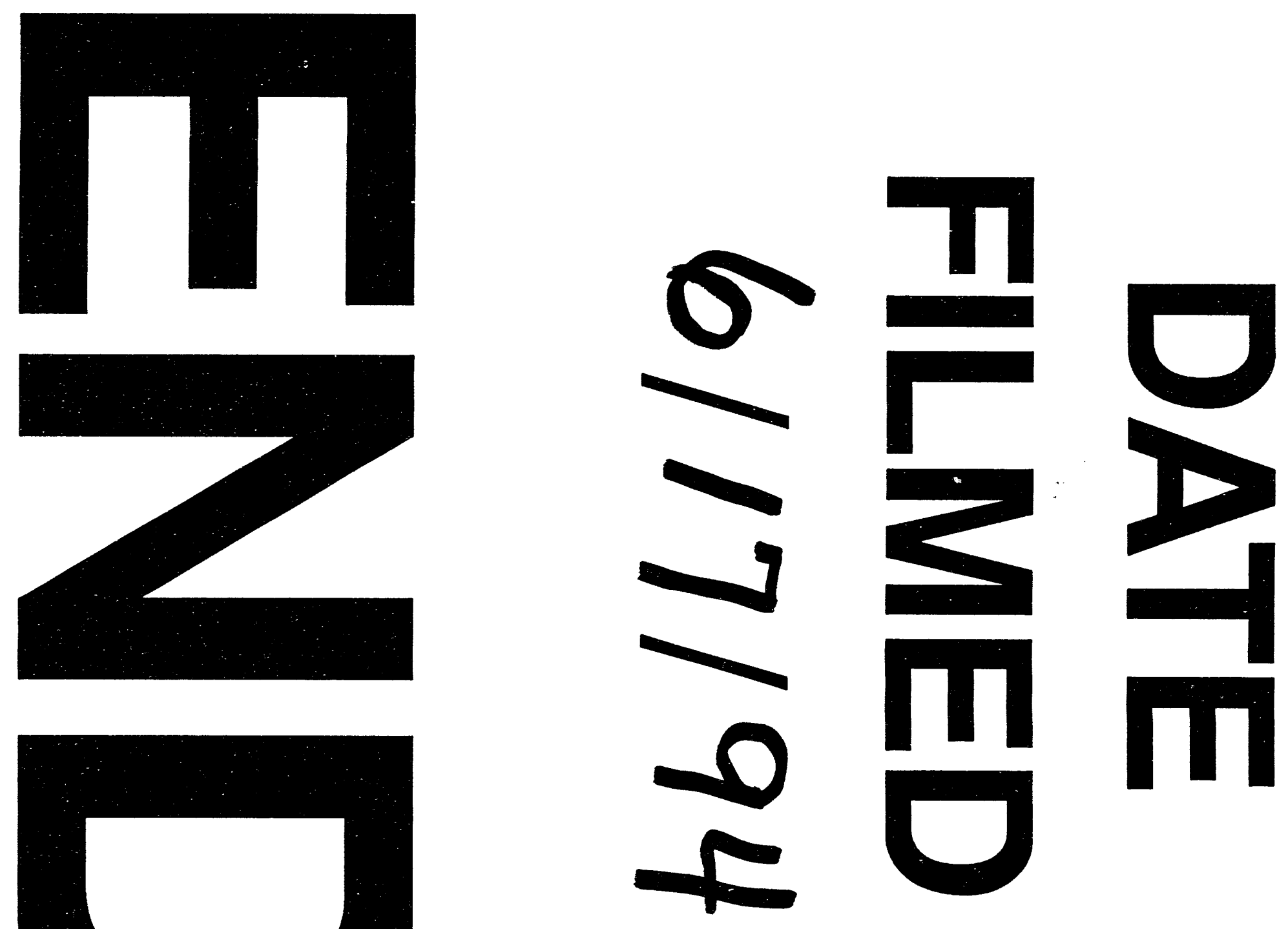
